le portiQue $\begin{array}{ll}\text { Le Portique } \\ \text { Revue de philosophie et de sciences humaines }\end{array}$

$18 \mid 2006$

Heidegger. La pensée à l'heure de la mondialisation

\title{
Des nouvelles du [parlement des philosophes]
}

\section{(2) OpenEdition \\ 1 Journals}

Édition électronique

URL : https://journals.openedition.org/leportique/837

DOI : 10.4000/leportique.837

ISSN : $1777-5280$

Éditeur

Association "Les Amis du Portique"

Édition imprimée

Date de publication : 1 septembre 2006

ISSN : 1283-8594

Référence électronique

"Des nouvelles du [parlement des philosophes] », Le Portique [En ligne], 18 | 2006, mis en ligne le 17 octobre 2006, consulté le 20 février 2023. URL : http://journals.openedition.org/leportique/837 ; DOI https://doi.org/10.4000/leportique.837

Ce document a été généré automatiquement le 20 février 2023.

Tous droits réservés 


\section{Des nouvelles du [parlement des philosophes]}

1 Au premier semestre de 2006, le [parlement des philosophes] a tenu plusieurs de ses sessions à Strasbourg. La plus importante a été consacrée en février à Emmanuel Levinas, à l'occasion du centenaire de sa naissance. On sait que, fuyant les pogromes de sa Lituanie natale, il était venu au début des années 1920 étudier la philosophie à l'Université de Strasbourg, et que ces années de formation où il avait découvert la phénoménologie de Husserl et s'était lié d'amitié avec Maurice Blanchot avaient beaucoup compté pour lui. Une vingtaine de chercheurs français, américains, belges et israéliens ont discuté de différents aspects de son œuvre devant une assistance nombreuse et attentive. Ces journées se sont achevées par l'audition de pièces musicales de son fils, Michaël Levinas, en présence du compositeur.

2 Au printemps, le [parlement des philosophes] a accueilli lors de deux journées d'études des chercheurs italiens (sur le thème de la communauté) et des jeunes philosophes suisses (autour de la question Qui est Européen ?).

3 Des enregistrements vidéo de ces trois manifestations sont dès à présent disponibles sur son site :

www.parlement-des-philosophes.org

4 Pendant l'année universitaire 2006-2007, nous organiserons plusieurs journées d'étude (entre autres sur Kierkegaard le 19 octobre, sur la mondialisation le 15 décembre, sur l'animalité en mai 2007) et deux colloques. Le premier, qui aura lieu en février au Musée d'art moderne, sera centré sur Debord et la Société du spectacle - quarante ans après le «scandale de Strasbourg » qui avait fait largement connaitre les positions de l'Internationale Situationniste. Le second, en avril, sera consacré à la philosophie française contemporaine, dont notre Université aura été longtemps été l'un des foyers les plus actifs. Un séminaire se tiendra tous les mois sur Éducation, institution et révolution. Toutes les informations sur ces manifestations seront données sur notre site. 